\title{
NUTRITIVE VALUE OF DIFFERENT PARTS OF FIVE TYPES OF SOLENOSTEMON SCUTELLARIOIDES (L.) CODD. FROM LAMIACEAE FAMILY
}

\author{
J. Chetia and L.R. Saikia \\ Department of Life Sciences, Dibrugarh University, Dibrugarh, Assam, India \\ Email: junali.chetia@yahoo.com
}

\begin{abstract}
Solenostemon scutellarioides (L.) Codd. from Lamiaceae family are ornamental plants having medicinal value. As some of the Lamiaceae members (Mentha spp, Ocimum spp.) are used as vegetable food, the nutritional status of these ornamental plant samples were determined to gets an idea about their food value using standard laboratory methods. All the samples are found to have nutritional value above $300 \mathrm{cal} / \mathrm{kg}$. Young leaves of type 5 recorded highest nutritive values $(505.55 \mathrm{cal} / \mathrm{kg})$ than other tested types of $S$. scutellarioides. The ash, moisture, fat, protein and carbohydrate contents vary from type to type of $S$. scutellarioides. Perhaps all the selected plants are not equally used as food in spite of their importance as medicinal resource.
\end{abstract}

Key words: Solenostemon scutellarioides (L.) Codd., Lamiaceae members

\section{Introduction}

Lamiaceae has occupied an important position in the socio-cultural, spiritual, medicinal aspects of rural and tribal peoples of India with their various medicinal properties (Sankar et al., 1994; Singh and Majumdar, 1997; Umadevi and Ganasoundari, 1999; Prakash and Gupta, 2000; Mediratta et al., 2002). The fat, ash, moisture, carbohydrate, protein content and nutritive value of Lamiaceae members are also described by some workers (Edeoga et al., 2006; Kavitha et al., 2009; Idris et al., 2011; Khomdram et al., 2011; Koche et al., 2011; Mlitan et al., 2014; Tomescu et al., 2015).

Solenostemon scutellariodes (L.) Codd. is an ornamental aromatic perennial plant (Garcia and O'Neil, 2000; Prajapati et al., 2013) with various colours (De Loureiro, 1970). The plants are rich in phenolic compound and rosmarinic acid (Rasineni et al., 2008; Razzaque and Ellis, 1977; De-Eknamkul and Ellis, 1987; Petersen, 1991; Petersen and Simmonds, 2003; Bauer et al., 2004). It is a folkloric medicinal plant used to treat malarial fever, hepatopathy, renal and vesicle calculi, cough, chronic asthma, hiccough, bronchitis, helminthiasis, colic, convulsions, diarrhoea, epilepsy, arthritic inflammations (Kirtikar and Basu, 1975; Warrier et al., 1995). Some of the plants of Lamiaceae are used as vegetables and therefore, proximate analysis of the samples were done to have an idea about the nutritional status of these plants used as human food in addition to their medicinal importance.

\section{ANALYSIS \\ Materials and Methods}

Samples were collected from Dibrugarh district of Assam at their full bloomed stage. Different parts (young and mature leaves, inflorescence and stem) were separated and cleaned properly. The materials were air dried at room temperature. The stems were sliced before allowed to dry. After removal of surface water, the materials were wrapped with brown paper and allow sundry for complete dryness (less than 1-2 percent moisture content). The materials were grounded to fine powder using mortar and pestle and then in electric grinder. The fine powder was kept in air tight bottles for further analysis. 


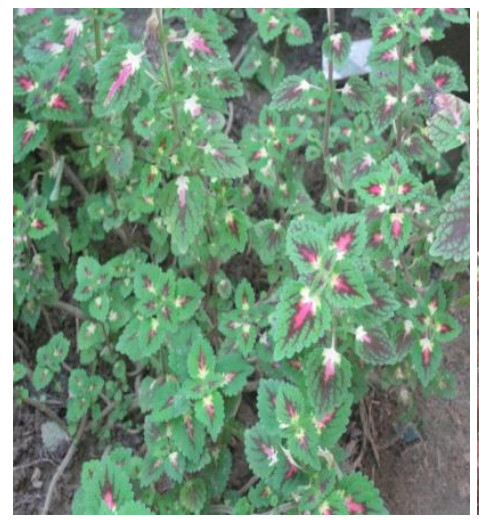

(a)

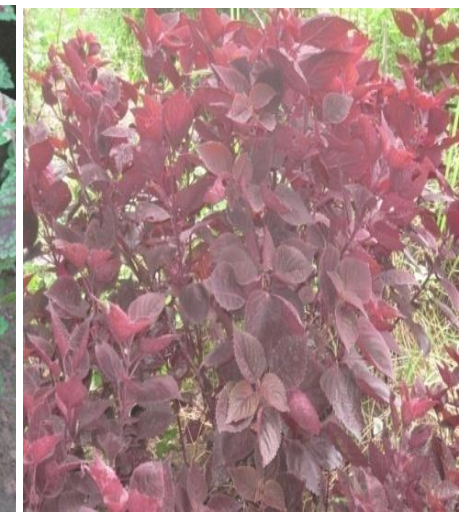

(b)

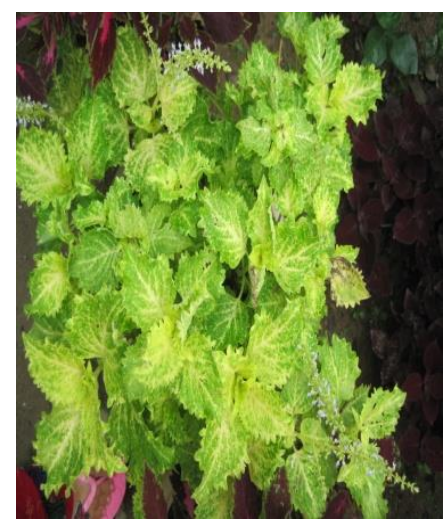

(c)

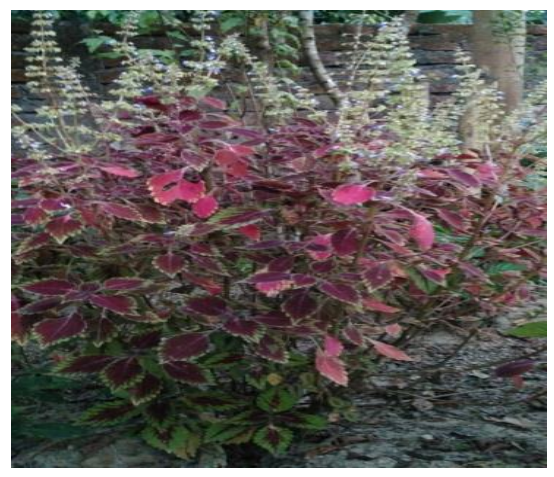

(d)

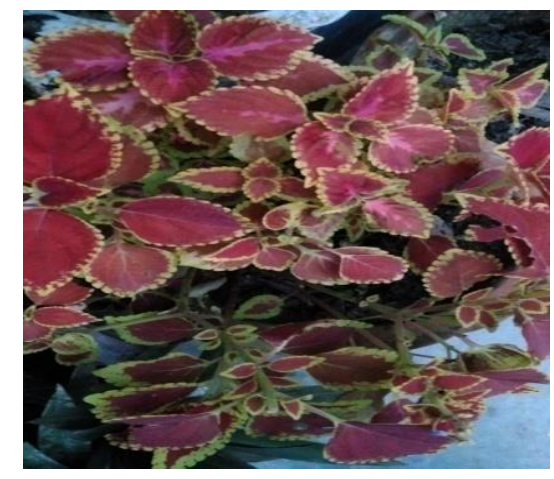

(e)

\section{Determination of Moisture Content}

Moisture content was determined by the method described by AOAC, 1990. $3 \mathrm{gm}$ of powdered sample was weighed in flat bottom disc and kept for $24 \mathrm{hrs}$ in a hot air over at $+80^{\circ} \mathrm{C}$ and finally weighed. The loss weight was regarded as a measure of moisture content.

\section{Determination of Ash Content}

$$
\text { Percent of Moisture }=\frac{\text { Wet. wt. }- \text { Dry Wt. }}{\text { Wet Wt. }} \times 100
$$

Ash content was determined by the method described by AOAC, 1990. $5 \mathrm{gm}$ of powdered sample was weighed in oven dried silica crucible. The crucible was heated first over a low flame till the material completely charred, followed by heating in a muffle furnace for 3 hours at $300^{\circ} \mathrm{C}$. It was cooled in desiccator and weighted. To ensure completion of ashing, it was heated again in the furnace for half an hour, cooled and weight. This was repeated consequently till the weight become constant wt.

$$
\text { Percent of Ash }=\frac{\text { Wt.ofAsh }}{\text { Wt. of Sample }} \times 100
$$

\section{Determination of Fat Content}

Fat content was determined by the method described by AOAC, (1990). $5 \mathrm{gm}$ of moisture free powdered sample was extracted with petroleum ether in a soxhlet extractor, heating the flask for about 6 hrs till a drop taken from dripping left no greasy stain on filter paper. After boiling with petroleum ether, the residual petroleum ether was filtered using whatman no. 40 filter paper and filtrate was evaporated in a pre-weighed beaker. Increase in weight of beaker gave crude fat.

\section{Determination of protein content}

$$
\text { Percent of fat }=\frac{\text { WeightoftheFat }}{\text { WeightoftheSample }} \times 100
$$

Protein content was determined by the Lowry method (Lowry et al., 1951)

\section{Determination of carbohydrate content}

Carbohydrate content was determined by using the formula as described by Indrayan et al., (2005) 
Percent of carbohydrate $=100-(\%$ of ash $+\%$ of Moisture $+\%$ of fat $+\%$ of Protein $)$

\section{Determination of nutritive value}

The nutritive value of the plant parts were determined by the method described by Indrayan et al., (2005).

Nutritive value $=4 x$ percentage of protein $+9 x$ Percentage of fat $+4 x$ Percentage of carbohydrate.

Nutritive value was expressed in $\mathrm{Cal} / \mathrm{Kg}$ of powder

\section{Results}

Ash content (percent) was recorded highest (5.70 \pm 0.50 percent) in mature leaves of type 1 .

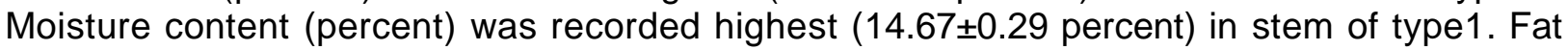
content (percent) was recorded higher $(34.00 \pm 0.04 \%)$ in young leaves of type 5 . Protein content of different parts of five types ranges from 0.010 percent to 0.080 percent. Young leaves of type 1 recorded highest protein content as 0.080 percent. Highest carbohydrate content was recorded by stem of type 4 (92.84 percent). Kavitha et al., (2009) recorded protein content as 61.4 to $90.5 \mathrm{mg} / \mathrm{g}$ in 37 genotype of $S$. scutellariodes. All the samples are found to have nutritional value above $300 \mathrm{cal} / \mathrm{kg}$. Perhaps all the selected plants are not equally used as food in spite of their importance as medicinal resource. The study of Khomdram et al. (2011) provides information on nutritive value of some selected plants of Lamiaceae collected from Manipur. Carbohydrate, soluble amino acid and protein were recorded in variable quantities in their samples. Perhaps these plants may contain some anti-nutritional factor as reported by Vasconcelos and Oliveira (2004); Mattila et al., (2018). Gemede and Ratta, (2014) explained that the presence of cyanogenic glycosides, protease inhibitors, lectins, tannins, alkaloids and sapiens in the plants in higher quantities may cause anti-nutritional effect.

Table 01: Nutritive value of different parts of Solenostemon scutellarioides (L.) Codd. Type1

\begin{tabular}{|l|c|c|c|c|c|c|}
\hline \multicolumn{1}{|c|}{$\begin{array}{c}\text { Sample } \\
\downarrow\end{array}$} & $\begin{array}{c}\text { Ash } \\
(\%)\end{array}$ & $\begin{array}{c}\text { Moisture } \\
(\%)\end{array}$ & $\begin{array}{c}\text { Fat } \\
(\%)\end{array}$ & $\begin{array}{c}\text { Protein } \\
(\%)\end{array}$ & $\begin{array}{c}\text { Carbohydrate } \\
(\%)\end{array}$ & $\begin{array}{c}\text { Nutritive } \\
\text { value (cal/Kg) }\end{array}$ \\
\hline Young leaf & $1.81 \pm 0.03$ & $14.60 \pm 1.09$ & $2.60 \pm 2.00$ & $0.080 \pm 0.01$ & 80.91 & 347.36 \\
\hline Mature leaf & $5.70 \pm 0.50$ & $10.10 \pm 0.03$ & $2.35 \pm 0.09$ & $0.012 \pm 0.03$ & 81.83 & 348.52 \\
\hline Inflorescence & $3.00 \pm 0.22$ & $10.00 \pm 0.00$ & $1.67 \pm 0.46$ & $0.034 \pm 0.11$ & 83.84 & 350.53 \\
\hline Stem & $1.09 \pm 0.04$ & $14.67 \pm 0.29$ & $0.87 \pm 0.01$ & $0.012 \pm 0.90$ & 83.35 & 341.27 \\
\hline
\end{tabular}

Table 02:Nutritive value of different parts of Solenostemon scutellarioides (L.) Codd. Type 2

\begin{tabular}{|l|c|c|c|c|c|c|}
\hline \multicolumn{1}{|c|}{$\begin{array}{c}\text { Sample } \\
\downarrow\end{array}$} & $\begin{array}{c}\text { Ash } \\
(\%)\end{array}$ & $\begin{array}{c}\text { Moisture } \\
(\%)\end{array}$ & $\begin{array}{c}\text { Fat } \\
(\%)\end{array}$ & $\begin{array}{c}\text { Protein } \\
(\%)\end{array}$ & $\begin{array}{c}\text { Carbohydrate } \\
(\%)\end{array}$ & $\begin{array}{c}\text { Nutritive } \\
\text { value } \\
(\mathbf{c a l} / \mathbf{K g})\end{array}$ \\
\hline Young leaf & $1.43 \pm 0.01$ & $9.00 \pm 0.27$ & $2.90 \pm 0.00$ & $0.012 \pm 0.22$ & 86.65 & 372.77 \\
\hline Mature leaf & $2.33 \pm 1.11$ & $6.83 \pm 0.09$ & $3.30 \pm 0.01$ & $0.018 \pm 1.00$ & 87.52 & 379.85 \\
\hline Inflorescence & $1.70 \pm 0.99$ & $12.23 \pm 1.09$ & $2.00 \pm 0.38$ & $0.023 \pm 0.98$ & 74.04 & 354.27 \\
\hline Stem & $0.98 \pm 0.01$ & $12.78 \pm 1.12$ & $0.89 \pm 0.02$ & $0.013 \pm 0.22$ & 85.33 & 349.41 \\
\hline
\end{tabular}


Table 03: Nutritive value of different parts of Solenostemon scutellarioides (L.) Codd. Type 3

\begin{tabular}{|l|c|c|c|c|c|c|}
\hline \multicolumn{1}{|c|}{$\begin{array}{c}\text { Sample } \\
\downarrow\end{array}$} & $\begin{array}{c}\text { Ash } \\
(\%)\end{array}$ & $\begin{array}{c}\text { Moisture } \\
(\%)\end{array}$ & $\begin{array}{c}\text { Fat } \\
(\%)\end{array}$ & $\begin{array}{c}\text { Protein } \\
(\%)\end{array}$ & $\begin{array}{c}\text { Carbohydrate } \\
(\%)\end{array}$ & $\begin{array}{c}\text { Nutritive } \\
\text { value } \\
(\mathbf{c a l} / \mathbf{K g})\end{array}$ \\
\hline Young leaf & $2.84 \pm 0.00$ & $6.60 \pm 0.02$ & $4.60 \pm 0.02$ & $0.013 \pm 0.02$ & 85.95 & 385.23 \\
\hline Mature leaf & $1.96 \pm 0.07$ & $7.20 \pm 0.33$ & $5.81 \pm 1.00$ & $0.014 \pm 0.11$ & 85.02 & 392.42 \\
\hline Inflorescence & $1.75 \pm 1.00$ & $8.07 \pm 0.19$ & $2.48 \pm 0.11$ & $0.016 \pm 0.09$ & 87.69 & 373.12 \\
\hline Stem & $0.40 \pm 0.01$ & $8.72 \pm 0.23$ & $1.00 \pm 0.00$ & $0.010 \pm 0.09$ & 89.87 & 368.52 \\
\hline
\end{tabular}

Table 04: Nutritive value of different parts of Solenostemon scutellarioides (L.) Codd. Type 4

\begin{tabular}{|l|c|c|c|c|c|c|}
\hline \multicolumn{1}{|c|}{$\begin{array}{c}\text { Sample } \\
\downarrow\end{array}$} & $\begin{array}{c}\text { Ash } \\
(\%)\end{array}$ & $\begin{array}{c}\text { Moisture } \\
(\%)\end{array}$ & $\begin{array}{c}\text { Fat } \\
(\%)\end{array}$ & Protein (\%) & $\begin{array}{c}\text { Carbohydrate } \\
(\%)\end{array}$ & $\begin{array}{c}\text { Nutritive } \\
\text { value } \\
(\mathbf{c a l} / \mathbf{K g})\end{array}$ \\
\hline Young leaf & $3.01 \pm 1.00$ & $12.75 \pm 0.03$ & $3.89 \pm 1.11$ & $0.029 \pm 0.03$ & 80.32 & 356.42 \\
\hline Mature leaf & $2.00 \pm 0.44$ & $14.10 \pm 1.00$ & $4.00 \pm 0.03$ & $0.030 \pm 0.32$ & 79.87 & 355.60 \\
\hline Inflorescence & $1.89 \pm 0.00$ & $10.01 \pm 0.03$ & $2.01 \pm 0.99$ & $0.031 \pm 0.09$ & 86.05 & 362.44 \\
\hline Stem & $0.56 \pm 0.01$ & $5.50 \pm 0.01$ & $1.09 \pm 0.20$ & $0.014 \pm 1.00$ & 92.84 & 381.21 \\
\hline
\end{tabular}

Table 05: Nutritive value of different parts of Solenostemon scutellarioides (L.) Codd. Type 5

\begin{tabular}{|l|c|c|c|c|c|c|}
\hline $\begin{array}{c}\text { Sample } \\
\downarrow\end{array}$ & $\begin{array}{c}\text { Ash } \\
(\%)\end{array}$ & $\begin{array}{c}\text { Moisture } \\
(\%)\end{array}$ & $\begin{array}{c}\text { Fat } \\
(\%)\end{array}$ & $\begin{array}{c}\text { Protein } \\
(\%)\end{array}$ & $\begin{array}{c}\text { Carbohydrate } \\
(\%)\end{array}$ & $\begin{array}{c}\text { Nutritive } \\
\text { value } \\
(\text { cal/Kg) }\end{array}$ \\
\hline Young leaf & $2.36 \pm 0.04$ & $13.75 \pm 2.01$ & $34.00 \pm 0.04$ & $0.018 \pm 0.01$ & 49.87 & 505.55 \\
\hline Mature leaf & $2.76 \pm 0.01$ & $13.98 \pm 1.07$ & $10.00 \pm 1.01$ & $0.021 \pm 0.02$ & 73.24 & 383.04 \\
\hline Inflorescence & $2.09 \pm 1.11$ & $10.40 \pm 0.22$ & $8.57 \pm 0.99$ & $0.035 \pm 0.77$ & 78.91 & 392.89 \\
\hline Stem & $1.00 \pm 0.03$ & $6.50 \pm 0.01$ & $3.12 \pm 0.09$ & $0.012 \pm 0.09$ & 89.36 & 385.59 \\
\hline
\end{tabular}

\section{Conclusion}

This kind of study provides information about the nutritional quality of these plants and some of them can be used as supplementary source of human food. The plants may have nutritional value but they are still not considered as 'functional food' and are not well experimented.

\section{References}

1. Association of Analytical Communities (AOAC) (1990) Official Methods of Analysis. 15th Edn, Association of Official Analytical Chemists, Washington, DC. USA., 200-210.

2. Bauer N, Leljak-Levanic D, Jelaska S (2004) Rosmarinic acid synthesis in transformed callus culture of Coleus blumei Benth. Zeitshrift fur Naturforschung. 59(7-8):554-60.

3. Edeoga HO, Omosun G, Uche LC (2006) Chemical composition of Hyptis suaveolens and Ocimum gratissimum hybrids from Nigeria. African Journal of Biotechnology. 5: 892-895.

4. De-Eknamkul W, Ellis BR (1987) Tyrosine aminotransferase: the entry point enzyme of the tyrosine-derived pathway in rosmarinic acid biosynthesis. Photochemistry. 26:1941-1946.

5. Garcia JF, O'Neil RJ (2000) Effect of Coleus size and variegation on attack rates, searching strategy, and selected life history characteristics of Cryptolaemus montrouzieri (Coleoptera: Coccinellidae). Biological Control. 18: 225-234.

6. Gemede HF, Ratta N (2014) Antinutritional factors in plant foods: Potential health benefits and adverse effects. International Journal of Nutritional and Food Sciences. 3(4): 284-289. 
7. Idris S, lyaka YA, Ndamitso MM, Paiko YB (2011) Nutritional composition of the leaves and stems of Ocimum gratissimum. Journal of Emerging trends in Engineering and Applied Sciences. 2(5):801-805.

8. Indrayan AK, Sharma S, Durgapal D, Kumar N, Kumar M, (2005) Determination of nutritive value and analysis of mineral elements for some medicinally valued plants from Uttaranchal. Current Science. 89(7):1252-1255.

9. Kavitha, C, Vadivel E, Rajamani K (2009) Evaluation of Coleus forskohli for biochemical characters. Research Journal of Medicinal Plants. 3: 75-79.

10. Khomdram SD, Salam JS, Singh PK (2011) Estimation of nutritive indices in eight Lamiaceae plants of Manipur. American Journal of food Technology. 6(10):924-931.

11. Kirtikar KR, Basu BD (1975). Indian medicinal plants (2nd edition). Dehradun: International Book Distributors, 1971.

12. Koche D, Imran S, Shirsat R, Bhadange D (2011) Comparative phytochemical and nutritional studies of leaves and stem of three lamiaceae members. Research Journal of Pharmaceutical, Biological and Chemical Sciences. 2(3):1-4.

13. Lowry OH, Rosen rough NJ, Farr Al, Randall RJ (1951) Journal of Biological Chemistry 193- 256.

14. Mattila PH, Pihlava JM, Hellstrom J, Nurmi M, Eurola M, Makinen S, Jalava T, Pihlanto A (2018) Content of phytochemicals and antimicrobial factors in commercial protein-rich plant products. Food quality and Safety. 2(4):213-219. Mazunder A, Neamati N, Sunder S (1997). Curcumin analogs with altered potencies against HIV-1 integrase as probes for biochemical mechanisms of drug action. Journal of Medical Chemistry. 40:3057-3063.

15. Mlitan AM, Sasi MS, Alkherraz AM (2014) Proximate and minor mineral content in some selected basil leaves of Ocimum gratissimum L. in Libya. International Journal of Chemical Engineering and Application. 5: 502.

16. Mediratta PK, Sharma KK, Singh S (2002) Evaluation of immunomodulatory potential of Ocimum sanctum seed oil and its possible mechanisms of action. Journal of Ethnopharmacology. 80:15-20.

17. Petersen MS, Simmonds MSJ (2003) Rosmarinic acid. Phytochemistry. 62:121-125.

18. Petersen MS (1991). Characterization of rosmarinic acid synthase from cell cultures of Coleus blumei. Phytochemistry. 30: 2877-2881.

19. Prajapati SK, Kaushik P, Malik A, Vijay VK (2013) Phycoremediation coupled production of algal biomass, harvesting and anaerobic digestion: possibilities and challenges. Biotechnology Advances. 31:1408-1425.

20. Prakash J, Gupta SK (2000). Chemopreventive activity of Ocimum sanctum seed oil. Journal of Ethnopharmacology, 72:29-34.

21. Sankar A, Lavania C, Pandey ON, Pant MC (1994) Changes in the blood lipid profile after administration of Ocimum sanctum (Tulsi) leaves in the normal albino rabbits. Indian Journal of Physiology and Pharmacology. 38:311.

22. Singh S, Majumdar DK (1997) Evaluation of anti-inflammatory activity of fatty acids of $O$. sanctum fixed oil. Indian Journal of Experimental Biology. 35: 380-383.

23. Tomescu A, Rus C, Pop G, Alexa E, Radulov I, Imbrea IM, Negrea M (2015) Research regarding proximate and selected elements composition of some medicinal plants belonging to lamiaceae family. Lucrari Scientific. 58(2):175-180.

24. Umadevi P, Ganasoundari A (1999) Modulation of glutathione and antioxidant enzymes by Ocimum sanctum and its role in protection against radiation injury. Indian Journal of Experimental Biology. 37:262.

25. Vasconceleos IM, Oliveira JT (2004) Antinutritional properties of plant Lectins. Toxicon. 44(4):385-403.

26. Warrier PK, Nambiar VPK, Ramankutty C. (1995) Indian Medicinal Plants. 1(5) Orient Longman Ltd., Madras. 